\title{
British Thermal Unit
}

National Cancer Institute

\section{Source}

National Cancer Institute. British Thermal Unit. NCI Thesaurus. Code C67196.

A non-SI unit of energy equal to the amount of heat required to raise the temperature of one pound avoirdupois of air-free water by one degree Fahrenheit at a constant pressure of one atmosphere. The value of the unit depends on the initial temperature of the water and varies in the range of approximately $1.054-1.060$ joules. 